\title{
Свойства квантовых ям и их применение в компактных лазерах ближнего ИК диапазона
}

\author{
Н.Н. Рубцова ${ }^{1}$, А.А. Ковалёв ${ }^{1}$, Д.В. Ледовских ${ }^{1}$, В.В. Преображенский ${ }^{1}$, М.А. Путято ${ }^{1}$, Б.Р. Семягин ${ }^{1}$, \\ С.А. Кузнецов ${ }^{2}$, В.С. Пивцов ${ }^{2}$ \\ ${ }^{1}$ ИФП СО РАН, 630090, Новосибирск, пр. Ак. Лаврентьева, 13 \\ ${ }^{2}$ ИЛФ СО РАН, 630090, Новосибирск, пр. Академика Лаврентьева, 155 \\ тел:+7 (383) 333-2769, факс:+7 (383) 333-2771, эл.nочта: rubtsova@isp.nsc.ru
}

DOI 10.34077/RCSP2021-72

Полупроводниковые зеркала с насыщающимся поглощением на базе квантовых ям являются ключевым элементом [1] для получения стабильного режима синхронизации мод многих лазеров.

Оптические свойства слоя квантовых ям определяют основные параметры оптических затворов на их основе.

В докладе сообщается о корреляции между строением квантовых ям (их состав, толщина барьеров, концентрация дефектов, степень согласованности по параметрам решетки материалов квантовых ям и барьеров и даже особенности технологии переноса слоев квантовых ям на диэлектрический широкополосный отражатель) и основными параметрами оптических затворов (механическая прочность, уровень ненасыщаемых потерь, максимальная глубина насыщения и быстродействие).

Экспериментально исследована кинетика отражения для нескольких вариантов квантовых ям (КЯ) из $\mathrm{In}_{0.25} \mathrm{Ga}_{0.75} \mathrm{As}$ с поглощением на экситонном переходе в области 1040 нм. Различие в структурах КЯ заключается в толщине и/или структуре барьеров. Использован одночастотный метод накачказондирование (pump-probe) [2] с временным разрешением 100 фс и предельной чувствительностью относительного изменения отражения $\Delta \mathrm{R} / \mathrm{R}=5^{*} 10^{-6}$. Кинетика отражения каждого образца представляет собой зависимость отражения от времени задержки между фемтосекундными импульсами накачки и пробного излучения ближнего ИК диапазона. Форма кинетической кривой отражения в каждом случае анализировалась в рамках модели [3], учитывающей вклад фотогенерированных эситонов, локализованных в квантовых ямах, и несвязанных электроннодырочных пар. Модель включает три характерных времени релаксации: $\tau_{1}-$ время ионизации экситонов при их взаимодействии с фононами, $\tau_{2}$ - время электронно-дырочной рекомбинации и $\tau_{3}-$ время установления квазиравновесия в коллективе электронно-дырочных пар после ионизации экситонов.

Для большинства образцов квантовых ям время $\tau_{1}$ составило 0,3-0,4 пс. Для квантовых ям типа $\mathrm{GaAs} / \mathrm{In}_{0.25} \mathrm{Ga}_{0.75} \mathrm{As} / \mathrm{GaAs}$ с толстыми барьерами порядка 10 нм GaAs время $\tau_{2}$ составляет 100-900 пс, разброс определяет латеральную неоднородность структур. Для КЯ с тонкими барьерами GaAs (3-5 ML) порядка 2 пс. На базе последней структуры разработано зеркало, использованное в лазере $\mathrm{Yb} 3+: \mathrm{KY}(\mathrm{WO} 4) 2$ с коротким резонатором. Получены импульсы с длительностью 200 фс с частотой следования 982 МГц [4].

Рассмотрены свойства слоя квантовых ям с идеальным согласованием материалов ям и барьеров по параметру решетки, обсуждаются перспективы их применения как основы для оптических затворов в лазероах с пассивной синхронизацией мод.

Исследование выполнено при поддержке гранта РФФИ № 18-29-20007

\section{Лumepamypa}

[1] U. Keller, K. J.Weingarten, F.X. Kärtner et al. IEEE J. Selected Topics in Quantum Electronics 2, 435 (1996).

[2] Г.М. Борисов, В.Г. Гольдорт, А.А. Ковалёв, Д.В. Ледовских, Н.Н. Рубцова, ПТЭ, 2018, №. 1,

[3] С. 87-91., ПТЭ, № 1, 87 (2018).

[4] Г.М. Борисов, В.Г. Гольдорт, А.А. Ковалёв, Д.В. Ледовских, Н.Н. Рубцова, Сибирский

[5] физический журнал,. 12, 109 (2017).-115.

[6] N.N. Rubtsova, A.A. Kovalyov, D.V. Ledovskikh, V.V. Preobrazhenskii,M.A. Putyato,

[7] B.R. Semyagin, S.A. Kuznetsov, V.S. Pivtsov and A.V. Semenko, Laser Physics, 30, 025001(2020). 